Article

\title{
Impact of a Balanced Scorecard as a Strategic Management System Tool to Improve Sustainable Development: Measuring the Mediation of Organizational Performance through PLS-Smart
}

\author{
Muhammad Rafiq ${ }^{1, *(1)}$, XingPing Zhang ${ }^{1}$, Jiahai Yuan ${ }^{1}\left(\mathbb{D}\right.$, Shumaila $\mathrm{Naz}^{2}{ }^{2}$ and \\ Saif Maqbool ${ }^{3}$ (1) \\ 1 School of Economics and Management, North China Electric Power University, Beijing 100000, China; \\ zxp@ncepu.edu.cn (X.Z.); yuanjH126@126.com (J.Y.) \\ 2 Faculty of Business and Management Sciences, The Superior College Lahore, Lahore 54000, Pakistan; \\ shumaila.superior@gmail.com \\ 3 National University of Computer \& Emerging Sciences, Chiniot-Faisalabad Campus, Chiniot 35400, Pakistan; \\ saif.maqbool@nu.edu.pk \\ * Correspondence: m.rafiq@ncepu.edu.cn; Tel.: +8615600458955
}

Received: 18 November 2019; Accepted: 11 February 2020; Published: 13 February 2020

check for updates

\begin{abstract}
The study was carried out to investigate the empirical effect of a strategic management system on sustainable development by using a balanced scorecard (BSC), as a theoretical lens, and organizational performance, as an intervening variable. The study incorporated a positivism research paradigm in order to address the objective nature of research. As the current study has an empirical and impartial nature, a quantitative method was considered the best method for achieving the research objectives of the study. The study used questionnaires as a data collection instrument. In total, three hundred questionnaires were disturbed among Chinese power companies based in Pakistan. A stratified-random sampling approach was adopted to reach relevant respondents. Partial least squares-structural equation modeling was used for statistical analysis. BSC indicated a positive influence on sustainable development. Additionally, organizational performance depicted partial mediation between the strategic management system and sustainable development. The study underpins the theoretical foundation of a resource-based view (RBV) and a balanced scorecard view of the strategic management system. The findings suggest that non-financial measures have better consequences for employees' performance, making them ecologically responsive, unlike the financial performance measures used previously. The study suggests taking measures related to wastage and usage of inimitable resources that focus on in-addition rather traditional measures, which can allow sustainable development.
\end{abstract}

Keywords: strategic management system; balanced scorecard; environmental sustainability and sustainable development

\section{Introduction}

The main goal of every organization is aligned with maximization of profit. This has labeled organizations as profit-making machines. This situation is the main reason for organizations to work more on their strategic management system to maximization their profitability along with long-lasting success. The stiff competition in today's dynamic environment is forcing the corporate world to strive for highly effective strategic systems that can enable organizations to work independently [1,2]. The competition invisibly invites organizations to work on a sustainable, inimitable, and rapidly 
adaptable strategic management system to enhance organizational performance effectively and efficiently. Traditionally, the corporate performance management system was deployed to attain financial outcomes, but later, non-financial measures became imperative for organizations $[3,4]$. Moreover, contributing to the environment as a factor of sustainable development is becoming a focus of the current era as it is defined as an organization's strategic outcome to make it stand-alone among competition $[5,6]$.

Kaplan and Norton [3] shifted attention from financial measures to a comprehensive performance management system. The current study benchmarks a balanced scorecard (BSC), as strategic management system (SMS) tool to translate critical organizational elements for growth [4]. Kaplan and Norton introduced a balanced card which suggested four perspectives to measure performance: (1) financial perspective (FP), (2) customer's perspective (CP), (3) internal business perspective (IBP), and (4) learning and growth perspective (LGP). BSC helps to develop a common and comprehensive point of reference for all employees and organizational business units. BSC as a strategic management tool is being used in many organizations to create a symmetry for effective control and to consider all relevant perspectives for sustainable success in a well-balanced way $[7,8]$. The success of implementing BSC is evident in the US, UK, Canada, Spain, China, and many more developed countries that have gained short- and long-term benefits. Fifty percent of US and UK organizations are using BSC as a strategic management system while Canadian, Jordan, and Chinese organizations are using BSC: $75 \%, 35 \%$, and $25 \%$, respectively [9-11]. This provides evidence that BSC is the best tool for improving organizational performance in all aspects [12]. It is imperative to align strategic management and sustainable development because without linking these two elements, none of the organizations can reduce the negative environmental and social impacts from business activities [13]. Additionally, a better organizational performance, in the presence of ecological intentions, triggers sustainable development which benefits sustainable corporate behavior. The purpose of this research is to investigate the empirical link of strategic management to sustainable development through organizational performance.

Keeping in view the significance of the strategic management system and its linkage to organizational performance and sustainable development, the study aims to explore the level of their interlinkage and its contribution to sustainable development. It is argued that most of the companies fail to execute strategies because of the following: (a) Only $5 \%$ of the employees know about the company's strategy, (b) $25 \%$ of managers can link the policy to incentives, (c) in $60 \%$ of the organizations, the link between budget and strategy is missing, and (d) discussion on strategy in $86 \%$ organizations is less than one hour [14]. Moreover, the environmental threat is becoming a serious and challenging issue for organizations. Therefore, the study is significant because it links the strategic management system with sustainable development within the context of ecological concerns. The BSC is studied in health, banking, educational, and telecom sectors in Pakistan, but the energy sector, the dominant sector of the country, is ignored by researchers [15-18]. After opening the doors for foreign investment in this sector, especially through 'belt and road initiatives', many power sector companies started investing in Pakistan. Hence, the study is helpful to the energy sector generally and to the Pakistan energy sector specifically. Therefore, there are two main reasons to select Pakistan as a contextual study. First, the study model has not been investigated in this context. Second, Pakistan is the main country of the Belt and Road Initiative project that has long-lasting impacts in the region. The study is fruitful for the energy sector to improve its strategic management systems and to contribute to ecological systems for sustainable performance. Chinese power companies have a major share in power generation as foreign companies in Pakistan. Almost twenty-four Chinese power companies are operating by and large in Pakistan [19]. The China National Electric Engineering Co., Ltd, the China Power Hub Generation Company, and State Grid of China are the largest Chinese companies working in Pakistan. The research focuses on these enterprises because such enterprises could have a generalizability impact due to the magnitude of their influence on other power generation 
sectors. These enterprises are fundamental sources of research and development for other power generation organizations.

The study aims to explore the impact of the strategic management system (SMS) on sustainable development (SD) by using organizational performance as a mediating variable. The study uses Smart-PLS for exploration of results analysis. The study adopts four perspectives of BSC. The perceived aspect of BSC is used in this study. Six items for perceived organizational performance and six items for sustainable development (SD) are taken as shown in Figure 1.

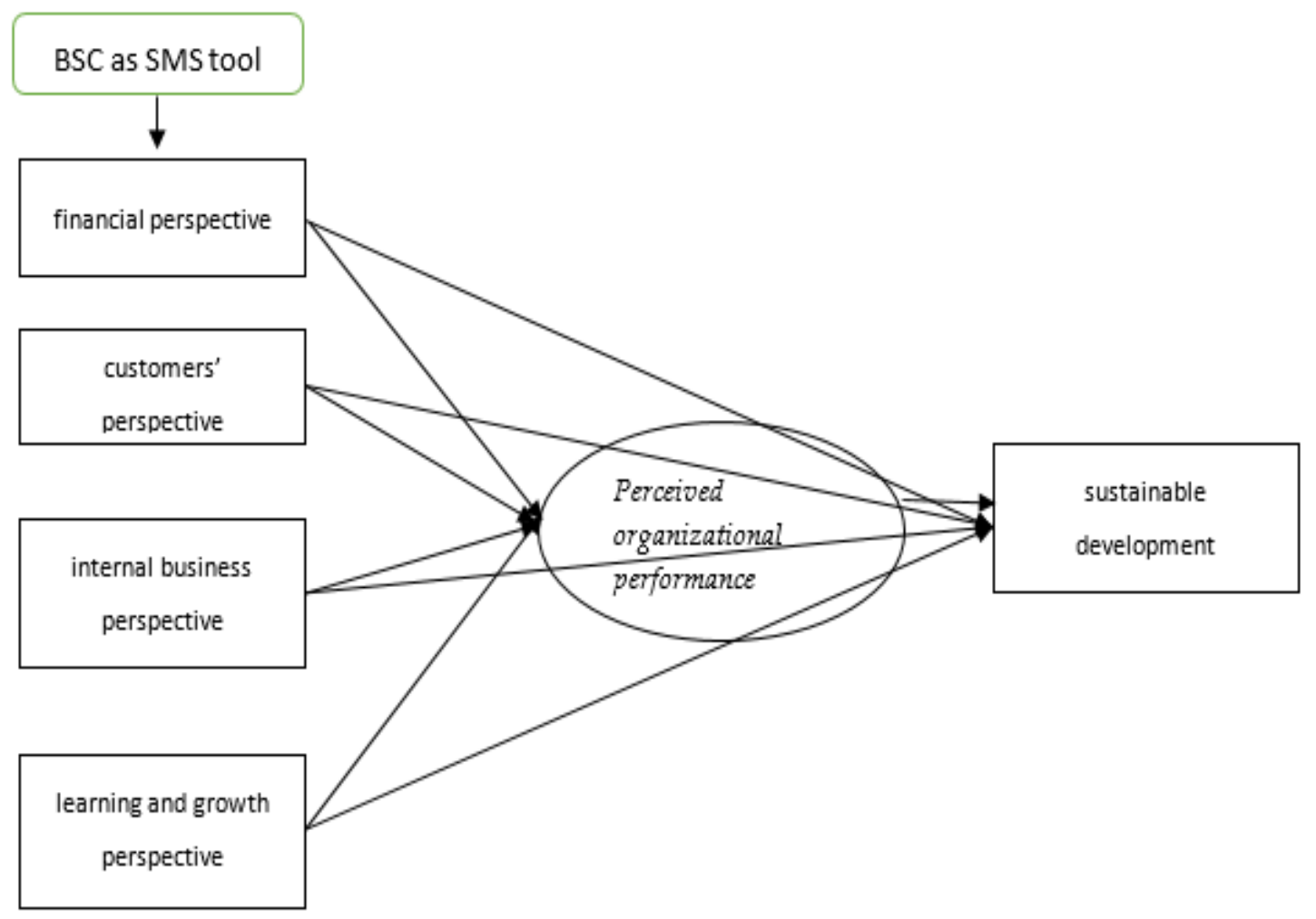

Figure 1. Theoretical Framework.

The article is organized as follows: the next chapter discusses literature reviews through which the relationship, in either way, between variables is obtained from previous studies. Chapter three narrates the research methodology, research instrument, and selection of research participants. Section 4 reports on data analysis using Smart-PLS and the interpretation of results. Section 5 entails the discussion and conclusion. The last part of the article discusses the limitations and future directions of the research.

\section{Literature}

In the current study, the perceived effect of three main variables is discussed (balanced scorecard as a measure of the strategic management system, organizational performance, and sustainable development). The four perspectives of the balanced scorecard, i.e., financial perspective, customers' perspective, internal business perspective, and learning and growth perspective, are discussed in detail, and their relationship with other variables is discussed. The study incorporated the perceived aspect of the balanced scorecard and the perceived aspect of its items such as the perceived aspect of finance, customers, the internal business process, and learning and growth. The (perceived) organizational performance is interpreted with respect to control and growth. The three main dimensions of sustainable development are discussed, such as economic, social, and environmental. This study only incorporates environmental perspective of sustainable development. Hence, it is imperative to consider inter-functional and conceptual relationships between these variables. The objective of taking perceived aspect of variables is because the survey is conducted among the employees at top, 
middle, and operational levels. Therefore, Section 2.1 explains the relationship between the strategic management system and balanced scorecard. This part emphasizes how strategic management goals are achieved through the balanced scorecard. Section 2.2 presents the relationship between the balanced scorecard and organizational performance; Section 2.3 indicates the influence of a balanced scorecard on sustainable development; and Section 2.4 elaborates the relationship between organizational performance and sustainable development. The last part, Section 2.5., indicates a holistic view in terms of a summary of the literature and the research framework used for the study, with hypotheses developed for the research.

\subsection{Linking the Strategic Management System with the Balanced Scorecard}

A strategic management system (SMS) is a set of actions and decisions that are articulated in the formulation and implementation of an organization's goals and objectives [20,21]. Furthermore, SMS is a comprehensive and integrated set of plans and effective implementation [22]. The late 1960's strategic management was established to develop a pragmatic performance system to differentiate between performers and non-performers [23-26]. To measure the performance differences, researchers have introduced many theories and approaches and even at an initial stage, they borrowed different methods from other fields and disciplines to streamline the process [27-32]. The issuance of academic journals at the international level, especially the Academy of Management Journal and Strategic Management Journal in the 1980s, played important roles in the acquisition and dissemination of knowledge to strengthen the strategic management discipline [29,33]. Likewise, the evolution of SMS was accelerated by two additional factors. First, different ontological and epistemological perspectives have influenced the subject because of heterogeneous and multidisciplinary nature of SMS [28,34]. Second, formulating and implementing strategies are the responsibility of managers as this lies in their electorate [35]. As per SMS research, two perspectives play a pivotal role in the survival of a company. The First is the content-oriented approach, which asserts strategies that seek attention to gain a long-term competitive advantage, especially for brand positioning [34,36]. Moreover, the resource-based view (RBV) is also supported in developing the foundations of SMS [37,38]. Second, the process-oriented approach is about when and how strategies can be established and applied to planning [39] and learning [40].

Strategy analysis, strategy formulation, strategy implementation, and strategy evaluation are four major chronological phases of SMS to continue it as a process [41-44]. SMS dealt the issues related to the firm's competitiveness and performance from the macro-level in earlier years [29]. Conversely, in current years, SMS has approached the issues from the micro foundation in its contemporary research paradigms. [31]. The strategy-as-practice and the practice-based view of strategy have contributed greatly in developing a comprehensive road map of SMS and organizational performance, which determines organizational success or failure [45-48]. The induction of a balanced scorecard leads the strategic management system to empirical achievements.

Initially, a balanced scorecard was perceived as a performance measurement instrument, but now, organizations are far beyond just reporting the past [3]. What we measure has an impact on the future because the measures taken by managers of organizations communicate conscious and subliminal messages to all business units and employees. Conceiving the edge of this organizational power, companies started integrating these measurement systems into their strategic management system. Hence, the BSC concept evolved as an organizing framework for managers rather than the performance management system. Even more, it worked as an operating tool for strategic management systems $[3,4,46,49]$.

\subsection{Balanced Scorecard and Organizational Performance}

The author explored that within two or three years of implementing this new strategic management system, organizations achieved significant breakthroughs in their whole systems, especially in performance across the board [4]. The early adopters achieved tremendous results with the power of BSC as SMS that focused on the entire organizational strategy. The speed of results through BSC 
strategies depict that organizations' success is not because of a new-service launch or product extension or new venture capitalization, but is due to process development and maturity through a strategic management system as a consequence of BSC application [50]. Nevertheless, the companies extend their services and products and invest heavily in tangible and intangible assets, but their success in terms of sustainability merely depends on systems they adopt for future growth. The previously hidden or frozen assets and capabilities are unleashed by new strategies and the BSC, which are helpful in a long-lasting value creation process [51].

The concept of organizational performance is highly integrated with strategy execution through the balanced scorecard. Figge, Hahn [52] described 'non-financial' measures as supportive factors for enhancing organizational performance through motivational factors [53]. The researchers also cited budgeting, scheduling, and formal program implementation as useful elements for optimum resource allocation and for identifying the key indicators for performance. As stated by Farid and Mirfakhredini [54], the financial perspective leads to tangible output in financial matters to increase organizational performance. Financial perspective includes return on investment, accounts payable \& receivable, earning per share, operating expenses, etc. FP (financial perspective) is also helpful to materialize the organizational goals [55]. Hypothesis 1 is postulated as follows:

\section{Hypothesis 1 (H1). Financial Perspective positively influences Perceived Organizational Performance.}

BSC is a comparatively new notion that ensures best performance practices and yields fruitful results for organizations as compared to past practices [18]. Customers' perspective of BSC incorporates the notion of customer satisfaction, customer retention, and customer acquisition. Furthermore, it makes organizations support flexibility, characterization in operation, and independence in decision making to a certain level to increase a firm's performance [56]. Thus, it can be postulated that customers' perspective influences organizational performance. Hence:

Hypothesis 2 (H2). The Customers' Perspective positively influences Perceived Organizational Performance is developed.

'What you measure is what you get', Kaplan and Norton [3] laid the foundation for the balanced scorecard to gauge the organizational performance. Before the induction of BSC, financial measures were the primary instrument to access a firm's performance. As a result, non-financial indicators were ignored, such as learning and growth. Financial measures focused on traditional performance management systems; as a result, improper measures encountered the behavior of dysfunctional conflicts and ignored the strategic importance of performance management in the organization [57,58]. Internal business processes and learning and growth are among the major sources of organizational growth [59]. The balanced scorecard is a performance tool that enhances organizational communication, which leads to learning new ideas within an organization and ultimately supports internal business processes [18]. The internal business process of the balanced scorecard indicates business operations, reworks, reductions in operational costs, etc. Hence, a number of studies refer to broadening the scope and coverage of the internal business process, which recommends a more comprehensive system of organizational performance that can contribute to the long-term success of an organization [60-65]. Hence,

Hypothesis 3 (H3). The Internal Business Perspective positively influences Perceived Organizational Performance.

Learning and growth perspectives of the BSC include research and development, employees' morale, employees' suggestions, etc. Ferreira and Otley [59] mentioned the need for identifying the multi-faceted concept of learning and growth to satisfy the ever-demanding need of organizational performance. Therefore, 
Hypothesis 4 (H4). The Learning and Growth Perspective positively influences Perceived Organizational Performance.

As time passed, BSC became a framework for converging vision and strategy into practice. It provided a comprehensive mechanism for stakeholders or executives that can translate a firm's strategic goals into an aligned and coherent set of performance procedures [7]. Researchers believe that a firm's strategic plans can be executed by practicing BSC in order to increase organizational performance [66]. Moreover, it is also claimed that consequences largely depend on how the notion of BSC is inferred, understood, and implemented by the businesses. In many cases, BSC produces different results for different organizations as one organization takes and implements BSC as a performance management system, while other organizations adopt it as a tool for strategic management systems [12]. Hence, this study takes BSC as a tool for a strategic management system.

\subsection{Balanced Scorecard and Sustainable Development}

For many years, the field of strategic management considered sustainable development as a secondary business function, but contemporary businesses consider it a primary and pivotal business function to grow. It is imperative to devise the right mechanism which can ensure organizational practices rightly focus on sustainability $[67,68]$. Therefore, there is a dire need to understand the basic notion of sustainable development. Sustainable development is described as progressing economically without the depletion of natural resources and without compromising environmental sustainability [57]. Moreover, it has a major focus on economic development, environmental sustainability, and social values. The study incorporates the notion of environmental sustainability, one component of sustainable development. The balanced scorecard works together with sustainable development by establishing basic level strategies for organizations to operate smoothly and responsively toward future goals. Due to this demand for devising mechanisms for sustainable development, the balanced scorecard is an emerging field of integrating these two essential concepts that are key players for long-lasting organizational success. Companies have to improve their management system due to increasing pressure to ensure a significant improvement in productivity and effectiveness, as well as to make the system secure but easy to understand and prompt to apply without harming nature. Besides, it must be a holistic management model that can ensure high-quality business operations with an emphasis on environmental safety [68]. Therefore, it is mandatory to find recommendations from literature which can help to design a strategic management system that is deeply rooted in sustainability [69].

The extended form of the balanced scorecard, widely known as a sustainable balanced scorecard, integrates BSC's four perspectives into sustainability [70]. Moreover, the natural evaluation of strategic thinking that meets the expectations of the environment and society is a known sustainable strategic management system provided that its political and regulatory factors are stable to support the business environment [71,72]. Moreover, a number of researchers stress the potential gains and contribution of a balanced scorecard for sustainable development in order to have a competitive advantage [52,73,74]. They promulgated a balanced scorecard as a trigger for sustainable development. Several researchers paid attention to align the customer's perspective and financial perspective with the economic dimension of sustainability [75-77]. Hence,

Hypothesis 5 (H5). The Financial Perspective positively influences Sustainable development.

The customers' perspective of a balanced scorecard is an integral measure of BSC that has an extended contribution to sustainable development [52]. Additionally, it is asserted that customers' perspective has a deeper influence to meet the sustainable development goals of the organizations. Therefore,

Hypothesis 6 (H6). The Customers' Perspective that positively influences Sustainable development is proposed. 
A greater number of organizations than ever before have started focusing on the idea of sustainability as their natural process of the strategy being executed in order to make sustainability a routine matter of the organization [78]. Resultant social and environmental domains of sustainability also attracted the attention of researchers alongside the economic domain. Nevertheless, most of the studies investigated all domains of sustainability at once [79]. Hence, the studies investigated the relationship between the internal business perspective of BSC with the environmental aspect of sustainability and the learning and growth perspective of BSC with the social domain of sustainability $[52,75-77,80]$. Therefore, the above literature postulates the hypothesis for the study:

Hypothesis 7 (H7). The Internal Business Perspective positively influences Sustainable Development.

The implementation of learning and the growth perspective of the BSC concept have not only changed the perspective and perception of the implementation process of organizational strategy but also depicted the desire for the need to integrate the process of sustainable development for future growth [81].

Hypothesis 8 (H8). The Learning and Growth Perspective positively influences Sustainable Development.

\subsection{Organizational Performance and Sustainable Development}

A well-performing organization can successfully take up the endeavors of sustainable development that is becoming urgent for every business [15]. Organizational performance has multifaceted concepts and applications [82]. Moreover, contributing beyond the financial gains is becoming a hallmark in order to become an environmentally friendly organization. Hence, organizational performance has recently become an influential factor for sustainable development $[15,76]$. Non-environmental degradation has become important in environmental economics. Furthermore, in this concept, companies are compelled to not use scarce resources abundantly without paying the social cost. Therefore, this view of sustainability in research is pivotal. Driving businesses consciously in a sustainable way is becoming urgent for many organizations nowadays; therefore, they are exerting maximum efforts to obtain better performance with respect to the environment [83]. Many organizations fail to implement environmental policies because they consider environmental sustainability a mere adaptation to current environmental legalities but ignore the necessity of board engagement and involvement of the whole value chain system $[84,85]$. Another expression recommends changing the approach to improve environmental performance from a responsive approach to a proactive strategic approach supplemented with an organizational orientation by placing stress on social issues and environmental concerns [86,87]. According to [6], environmental performance is defined as 'the outcome of a firm's strategic activities that manage (or not) its impact on the natural environment'. As a result, management literature focuses on taking serious steps to make sustainable development a part of the organizational process. Recently, researchers have paid particular attention to environmental sustainability by focusing on the strategic orientation of an organization in a way that sets environmental sustainability as a priority and part of the organization's operation to whom customers view as having a competitive advantage [84]. It is worth mentioning that strategic orientation is mainly described as a generic culture of an organization. Eventually, companies have to decide to implement strategies and orient their organization, which can ensure specific procedures in the management systems and planning where organizations need it [88]. Hence, many studies have talked about the effect of the strategic management system and the firm's orientation on organizational environmental output [89-92]. On the other hand, these studies highlight some contradictions with respect to the same phenomena, as SMS and organizational orientation do not influence environmental performance. Further exacerbation on this issue reveals that the lack of objective measurement of environmental performance has created numerous problems. This shortcoming, lack of exact measures of the effect of strategic management on environmental performance, hinders researchers from taking certain decisions and implementing 
procedures about environmental sustainability at the firm level. Besides this, the search in this field is gearing up and advancing to devise solid policies for organizational long-term success through environmental sustainability [5]. Therefore, the above literature postulates the following hypothesis:

Hypothesis 9 (H9). Perceived Organizational Performance positively influences Sustainable Development

\subsection{Research Framework}

Increasing implementation of BSC is causing desired organizational outcomes such as improved performance. Researchers are adopting BSC as a performance measurement tool to improve organizational sustainability. However, effects vary from a highly evident effect to a slight indirect effect and no effect. A few researchers claim that organizations' BSC can enhance organizational performance by making a good strategic plan of action [66]. However, few other researchers stated that it is difficult to proclaim the relationship between BSC implementation and organizational performance $[12,93]$. Indeed, the disparity of opinion may be attributed to the fact of how BSC's notion is understood, inferred, and practiced by organizations, as implementing it as a strategic management tool has different outcomes than implementing it as a performance management system [12]. Also, performance outcomes encourage organizations to fulfill their commitments towards environmental sustainability. In a nutshell, there is an opportunity for investigating the relationship between BSC and organizational performance with perspective to control and growth [94] and even to explore the relationship between organizational performance and environmental sustainability $[64,78,95]$. Figure 2 shows the research framework signifying the hypothesis postulated in order to understand the possible links among variables.

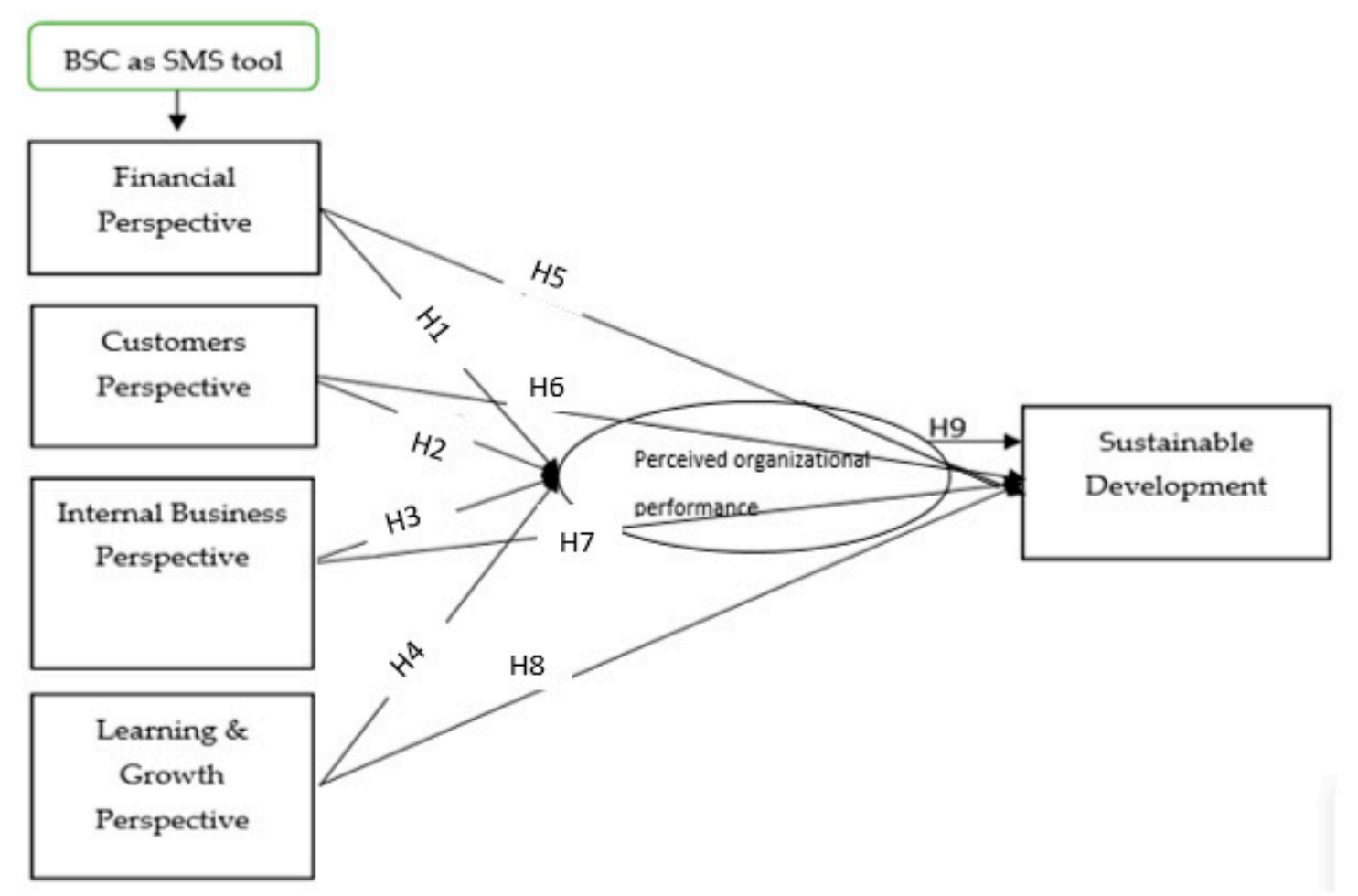

Figure 2. Research Framework.

\section{Research Methodology}

This segment of the research contains the methodology, the instrument, data collection tool, and sampling techniques used in the study to investigate the relationship between the strategic management systems and sustainable development. This study uses organizational performance 
as a mediating variable in the context of Chinese power corporations operating in Pakistan. The study incorporates a positivism research paradigm in order to address the objective nature of research questions, as suggested by [96]. As the current study has a practical and impartial nature, the quantitative method is considered the best method for achieving the research objectives of the study $[96,97]$. Moreover, the deductive approach is the most suitable approach to achieve the objective of generalization. Therefore, the current research is clear and justifies the research methodology, positivism, in order to carry on the further process of data collection and sampling.

\subsection{The Instrument}

The data collection tool is one of the most integral and pivotal parts of the study. The study instrument was divided into four main parts: Section 1, demographics; this section captures the respondents' profiles such as age, sex, designation, experience, etc. Section 2, BSC, the strategic management system, measures four perspectives (a) financial, (b) customer, (c) internal business process, and (d) learning and growth. Section 3, performance, explains fundamental elements of organizational performance such as control, growth, etc. Section 4, sustainable development, gauges the factors related to sustainable development with respect to the ecological system. Aligned with the research paradigm, the close-ended questionnaire is designed to ensure the unbiased responses of participants. The questionnaire is a five-point Likert scale, ranging from strongly disagree to strongly agree, valued 1-5; one is the least, and five is the highest. The instrument was adapted from the study of $[65,98]$. The questionnaire was adapted and changed contextually as per the discussion with experts and the outcome of the pilot study. The pilot study from fifty respondents was done to ensure the appropriateness of the instrument. The varimax rotation from principal component analysis and confirmatory factor analysis were run to drop unjustified variables and to retain prominent drivers [99]. Further, the reliability test was also used to ensure the trustworthiness of the instrument. All values of Cronbach's alpha were above 0.80 , which indicates acceptable internal reliability [100].

\subsection{Sampling}

As a case study, two Chinese power companies were selected for this research. (1) China National Electric Engineering Company - CNEEC Pakistan, which has actively worked in Pakistan since 2012 on thermal, solar, and wind forms of energies and (2) China Power Hub Generation Company (CPHGC). Due to time-bound and restrictions to civilians to visit these projects, only these two companies were selected as samples for the study. These companies are among the major contributors to energy projects established in Pakistan under the China-Pakistan Economic Corridor (CPEC). A random sampling approach was adopted to reach a relevant sample of the population from these companies.

The sample size was calculated through Rao-soft software (Rao-soft, Inc. 2011, Seattle, WA, USA), which suggests the sufficiency of respondents as Equations (1)-(3):

$$
\begin{gathered}
x=Z\left({ }^{\mathcal{C}} / 100\right)^{2} r(100-r) \\
n=N x /\left((N-1) E^{2}+x\right) \\
\mathrm{E}=\operatorname{Sqrt}[(N-n) x / n(N-1)]
\end{gathered}
$$

Three hundred and eighty questionnaires were distributed to top management (30\% of total questionnaires), and $70 \%$ of questionnaires were distributed to middle-level management. In total, 300 respondents returned the questionnaire or filled it in appropriately. Incomplete questionnaires were eliminated from the study. It was confirmed that respondents were familiar with the concepts of the instrument, either working directly on the same nature of the system or with the capacity to understand and implement the instrument. 


\section{Analysis}

\subsection{Demographics}

Table 1 indicates the descriptive statistics of the participants who contributed to the study. As per the following statistics, it is notable that male participants contributed more than females. Almost 73 percent of the participants were male, and 22 percent were female. Furthermore, it is pivotal to know about the age of respondents. The majority of the participants were youngsters. Those from 31-35 years old were in the majority, with a percentage of 24.9. The second highest participating age category was 41-45 years old, who contributed 10.5 percent. Middle-level management contributed most to the study. The participation from the middle level was 68.5 percent. Moreover, the experience is another factor that can influence the significance of the study. The following table specifies that 35.7 percent of participants had 5-7 years of experience, followed by 2-4 years, with a percentage of 27.5 .

Table 1. Demographics.

\begin{tabular}{|c|c|c|c|}
\hline \multicolumn{2}{|r|}{ Items } & \multirow{2}{*}{$\begin{array}{c}\text { Frequency } \\
222\end{array}$} & \multirow{2}{*}{$\begin{array}{c}\text { Percent } \\
72.8\end{array}$} \\
\hline Gender & Male & & \\
\hline Gender & Female & 68 & 22.3 \\
\hline \multirow{7}{*}{ Age } & $20-25$ & 14 & 4.6 \\
\hline & $26-30$ & 25 & 8.2 \\
\hline & $31-35$ & 76 & 24.9 \\
\hline & $36-40$ & 70 & 23 \\
\hline & $41-45$ & 62 & 20.3 \\
\hline & $46-50$ & 32 & 10.5 \\
\hline & Above 50 & 17 & 5.6 \\
\hline \multirow{3}{*}{ Designation } & Upper level & 18 & 5.9 \\
\hline & Middle level & 209 & 68.5 \\
\hline & Operational level & 69 & 22.6 \\
\hline \multirow{4}{*}{ Experience } & Less than 2 years & 44 & 14.7 \\
\hline & Between 2 and 4 years & 84 & 27.5 \\
\hline & Between 5 and 7 years & 109 & 35.7 \\
\hline & More than seven years & 58 & 19 \\
\hline
\end{tabular}

Reliability values are indicated in Table 2. Cronbach's Alpha, composite, and average variance extracted reliability methods were applied to ensure the trustworthiness of research. Tavakol and Dennick [101] asserted that Cronbach's alpha ranges from 0.70 to 0.95 , although there are different reports about its acceptability. Poor inter-relatedness between items or heterogeneous constructs and a smaller number of questions are possible reasons for having a low Cronbach's alpha. This study has a Cronbach's alpha reliability value between 0.884 and 0.798 , which are acceptable values.

Table 2. Reliability.

\begin{tabular}{cccc}
\hline Variables & $\begin{array}{c}\text { Cronbach's } \\
\text { Alpha }\end{array}$ & $\begin{array}{c}\text { Composite } \\
\text { Reliability }\end{array}$ & $\begin{array}{c}\text { Average Variance } \\
\text { Extracted (AVE) }\end{array}$ \\
\hline Internal business perspective & 0.875 & 0.910 & 0.670 \\
Customers' perspective & 0.884 & 0.912 & 0.632 \\
Financial perspective & 0.827 & 0.892 & 0.636 \\
Learning and growth perspective & 0.798 & 0.861 & 0.555 \\
Perceived organizational performance & 0.867 & 0.908 & 0.637 \\
Sustainable development & 0.798 & 0.857 & 0.502 \\
\hline
\end{tabular}

Moreover, the acceptable value of composite reliability (CR) is 0.70 or above, while an acceptable value of the average variance extracted (AVE) is 0.50 or above [102]. The minimum value of CR in 
this study is 0.857 which is above the minimum acceptable value, and AVE's minimum value in this study is 0.502 , which is above the minimum acceptable value. Hence, the level of variance captured by the construct (AVE) is acceptable, and the less biased estimate of reliability (CR) is also acceptable in this study.

\subsection{Discriminant Reliability}

For the measurement of discriminant reliability, the Fornel-Larcker criterion and cross-loading examination were applied primarily [103]. Conversely, the Fornel-Larcker method did not correctly measure the discriminant validity. Hence, the current study used other alternative methods such as the multitrait-multimethod matrix to measure discriminant validity. Heterotrait-monotrait correlation ration was also used. Henseler, Ringle [103] argued that the heterotrait-monotrait ratio must be less than 0.85 to confirm the discriminant validity. There is no issue of discriminant validity as all values in Table 3 are less than 0.85 . Discriminant reliability is useful to access the measurement error. It is used to correct the attenuation which helps to determine whether the concepts are related or unrelated.

Table 3. Discriminant reliability

\begin{tabular}{|c|c|c|c|c|c|c|}
\hline Variables & $\begin{array}{c}\text { Internal } \\
\text { Business } \\
\text { Perspective }\end{array}$ & $\begin{array}{l}\text { Customer } \\
\text { Perspective }\end{array}$ & $\begin{array}{l}\text { Financial } \\
\text { Perspective }\end{array}$ & $\begin{array}{c}\text { Learning and } \\
\text { Growth } \\
\text { Perspective }\end{array}$ & $\begin{array}{c}\text { Perceived } \\
\text { Organizational } \\
\text { Performance }\end{array}$ & $\begin{array}{l}\text { Sustainable } \\
\text { Development }\end{array}$ \\
\hline $\begin{array}{c}\text { Internal } \\
\text { business } \\
\text { perspective }\end{array}$ & 0.818 & & & & & \\
\hline $\begin{array}{c}\text { customer } \\
\text { perspective }\end{array}$ & 0.704 & 0.795 & & & & \\
\hline $\begin{array}{c}\text { financial } \\
\text { perspective }\end{array}$ & 0.710 & 0.821 & 0.797 & & & \\
\hline $\begin{array}{l}\text { learning and } \\
\text { growth } \\
\text { perspective }\end{array}$ & 0.412 & 0.523 & 0.488 & 0.745 & & \\
\hline $\begin{array}{c}\text { Perceived } \\
\text { organizational } \\
\text { performance }\end{array}$ & 0.563 & 0.650 & 0.723 & 0.561 & 0.798 & \\
\hline $\begin{array}{c}\text { Sustainable } \\
\text { development }\end{array}$ & 0.531 & 0.540 & 0.566 & 0.811 & 0.596 & 0.709 \\
\hline
\end{tabular}

Table 4 describes factor loadings to test the research model. All the items in the outer loading must be $(\leq 0.50)$. All the items were above the accepted value, except that a few items were not in the range of the accepted value. Their values were below the accepted range of 0.50 . After careful examination, the factors such as fp1 (financial perspective-1), lgp6 (learning and growth perspective-6), and op1 (organizational performance-1) were skipped as 20 percent of total items can be deleted [103]. The factor loadings of items are shown in Figure 3.

The factor loading Figure 3 depicts that in the financial perspective variable, item fp 3 has the highest value of 0.912 , and fp6 has the lowest value of 0.806 . While, in the perceived customer perspective variable, $\mathrm{cp} 1$ has the highest value, 0.834 , and cp6 has the lowest value in factor loading, 0.757. Additionally, the variable perceived internal business perspective has values between 0.885 and 0.745 , for ibp3, and ibp1, respectively. Moreover, the perceived learning and growth perspective variable's loading values range from 0.849 to 0.556 for $\operatorname{lgp} 1$ and $\operatorname{lgp} 5$, respectively. Furthermore, op 3 and op4 have loading values of 0.911 to 0.831 , respectively, for the perceived organizational performance variable. Lastly, the sustainable development variable's loadings are between 0.807 and 0.528 for sd2 and sd3, respectively. This suggests that unrelated constructs are eliminated in order to make data more reliable. Hence, applicants can rely on the study results while they are making decisions. 
Table 4. Confirmatory factor analysis.

\begin{tabular}{|c|c|}
\hline Items & Customers' Perspective \\
\hline cp1 & 0.838 \\
\hline cp2 & 0.804 \\
\hline cp3 & 0.793 \\
\hline $\mathrm{cp} 4$ & 0.788 \\
\hline cp5 & 0.789 \\
\hline \multirow[t]{2}{*}{ cp6 } & 0.756 \\
\hline & Financial perspective \\
\hline $\mathrm{fp} 2$ & 0.902 \\
\hline fp3 & 0.912 \\
\hline fp4 & 0.881 \\
\hline fp5 & 0.856 \\
\hline \multirow[t]{2}{*}{ fp6 } & 0.806 \\
\hline & internal business perspective \\
\hline ibp1 & 0.745 \\
\hline ibp2 & 0.856 \\
\hline ibp3 & 0.885 \\
\hline ibp4 & 0.795 \\
\hline \multirow[t]{2}{*}{ ibp5 } & 0.802 \\
\hline & learning and growth perspective \\
\hline $\operatorname{lgp} 1$ & 0.841 \\
\hline $\lg 2$ & 0.849 \\
\hline lgp3 & 0.764 \\
\hline $\lg 4$ & 0.651 \\
\hline \multirow[t]{2}{*}{$\lg 55$} & 0.556 \\
\hline & Perceived organizational performance \\
\hline op2 & 0.897 \\
\hline op3 & 0.911 \\
\hline op4 & 0.831 \\
\hline op5 & 0.881 \\
\hline \multirow[t]{2}{*}{ op6 } & 0.834 \\
\hline & Sustainable development \\
\hline sd1 & 0.528 \\
\hline $\mathrm{sd} 2$ & 0.807 \\
\hline $\mathrm{sd} 3$ & 0.802 \\
\hline $\mathrm{sd} 4$ & 0.755 \\
\hline sd5 & 0.751 \\
\hline sd6 & 0.549 \\
\hline
\end{tabular}

A particular diagram-based methodology was applied to explore the relationship between multivariate variables based on Wright (1921), through which the 'path coefficients' term was derived [104]. Path coefficients are uniform forms of linear regression weights that are used to explore the possible link between statistical variables in SEM (structural equation modeling) methodology. Table 5 illustrates the perceived values of the path coefficient that determine the existence or non-existence of relationships. H1 which indicates the relationship between the perceived financial perspective and perceived organizational performance is accepted. The values depict that $\mathrm{H} 1$ is accepted, and the resultantly perceived financial perspective has a positive influence on the perceived organizational performance. The $p$-value is less than 0.05 . H5 is not accepted, which means there is no relationship between the perceived financial perspective and sustainable development. The $\mathrm{P}$ and $\mathrm{T}$ values are beyond the accepted values; hence, the values predict that the perceived financial perspective does not positively influence sustainable development $(p=0.183, t=1.332)$. 


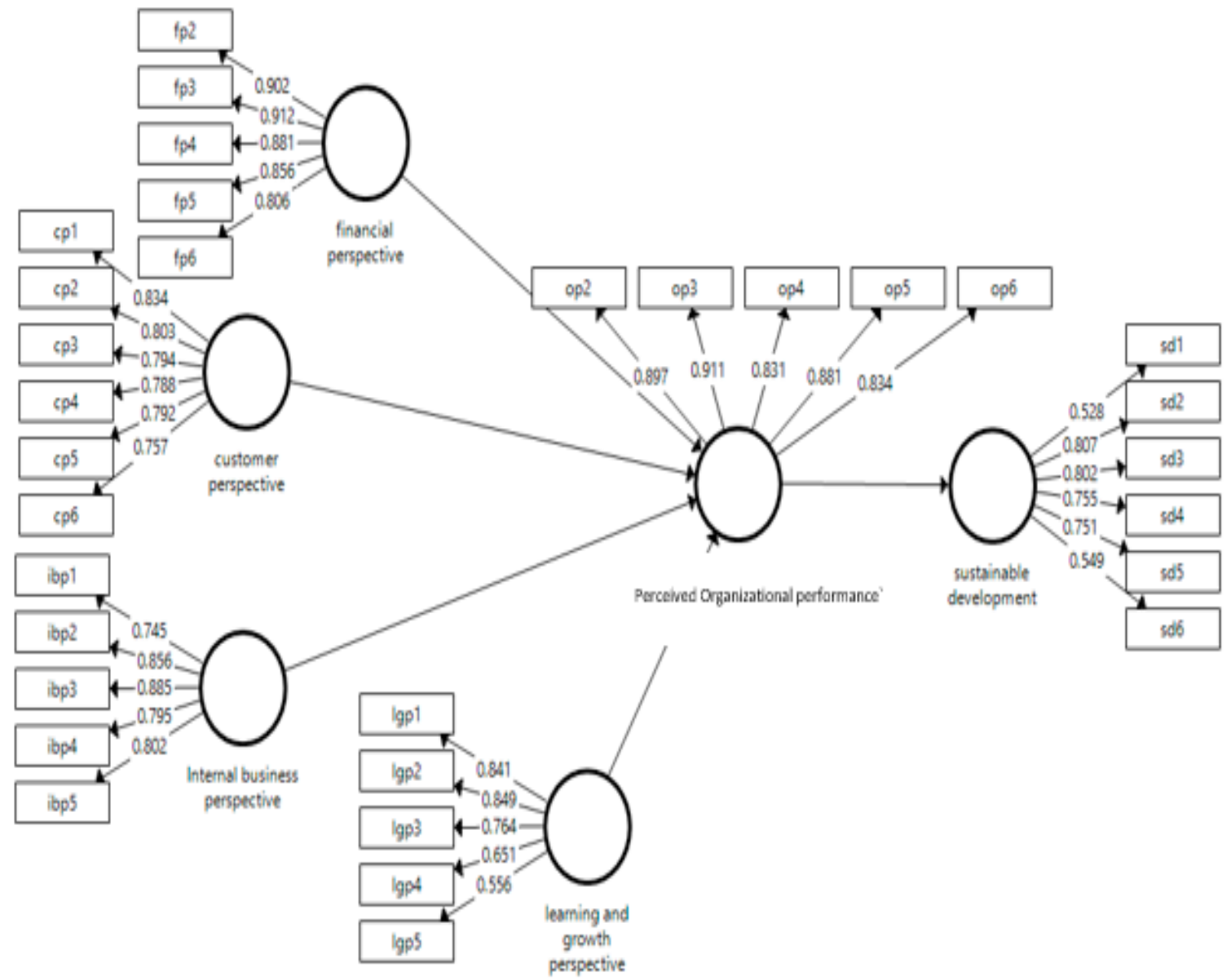

Figure 3. Confirmatory factor analysis.

Table 5. Path coefficient.

\begin{tabular}{cccccc}
\hline Hypothesis & Relationship & Standard Deviation & T Statistics & $p$-Values & Decision \\
\hline H1 & $\mathrm{FP} \rightarrow \mathrm{POP}$ & 0.167 & 4.381 & 0.000 & Accepted \\
\hline $\mathrm{H} 2$ & $\mathrm{CP} \rightarrow \mathrm{POP}$ & 0.204 & 3.461 & 0.034 & Accepted \\
\hline $\mathrm{H} 3$ & $\mathrm{IBP} \rightarrow \mathrm{POP}$ & 0.096 & 3.213 & 0.032 & Accepted \\
\hline $\mathrm{H} 4$ & $\mathrm{LGP} \rightarrow \mathrm{POP}$ & 0.076 & 4.375 & 0.000 & Accepted \\
\hline $\mathrm{H} 5$ & $\mathrm{FP} \rightarrow \mathrm{SD}$ & 0.268 & 1.332 & 0.183 & Rejected \\
\hline $\mathrm{H} 6$ & $\mathrm{CP} \rightarrow \mathrm{SD}$ & 0.237 & 2.046 & 0.041 & Accepted \\
\hline $\mathrm{H} 7$ & $\mathrm{IBP} \rightarrow \mathrm{SD}$ & 0.124 & 2.365 & 0.018 & Accepted \\
\hline $\mathrm{H} 8$ & $\mathrm{LGP} \rightarrow \mathrm{SD}$ & 0.112 & 9.021 & 0.000 & Accepted \\
\hline $\mathrm{H} 9$ & $\mathrm{POP} \rightarrow \mathrm{SD}$ & 0.169 & 0.509 & 0.611 & Rejected \\
\hline
\end{tabular}

Abbreviations: (FP) Financial Perspective, (CP) Customer's Perspective, (IBP) Internal Business Perspective, (LGP) Learning and Growth Perspective, (POP) Perceived Organizational Performance, (SD) Sustainable Development.

Similarly, $\mathrm{H} 9$ is also not accepted, which indicates no relationship between perceived organizational performance and sustainable development. The $p$-value of OP and SD is 0.611 , which is higher than 0.05; hence, this hypothesis is not accepted which resultantly denies the hypothesis that perceived organizational performance positively influences sustainable development. Hypotheses H2, H3, H4, H6, H7, and H8 are accepted in this study, which indicates that perceived customers' perspective, perceived internal business perspective, perceived learning, and growth perspective have a significant positive influence on perceived organizational performance and sustainable development. The $p$-values 
are in an acceptable range, as are the $\mathrm{f}$ and $\mathrm{t}$ values. The following table is useful for the practitioner to decide usage of the research model. It indicates model testing and the implications of consequences. The rejection and acceptance of the hypothesis are meaningful to the practitioners in order to set the clear direction of their organizations with respect to the usage of BSC concepts in their respective firms.

\section{Implications}

Primarily, the study was conducted to check the relationship between the strategic management system and sustainable development. SMS utilized BSC as a theoretical lens and sustainable development with respect to environmental sustainability. The research used perceived organizational performance as an intervening variable. The studies in the past did not explicitly explore the combination of BSC and sustainable development by including perceived organizational performance in existing settings [91,92]. Therefore, previous studies have fragmented pictures of the phenomenon and have revealed contradicting and inconsistent results. Therefore, making it possible to understand the concept in one go, the current study combines the BSC factors for the power sector, which is the hub of economies. It is worthwhile to consider that the organizational performance and sustainable development are measured with perceived aspects. Due to the limitation of the study, the operationalization of these effects is not measured among the different levels of management, such as the top, middle, and lower levels. Hence, it is caution for policy maker to consider this effect at the time of application.

Theoretical implications: Primarily, the study was conducted to check the relationship between the strategic management system and sustainable development. SMS utilized BSC as a theoretical lens and sustainable development with a perspective of environmental sustainability. The research used perceived organizational performance as an intervening variable. By bridging the gap mentioned, the current research significantly contributes to the literature of BSC, organizational performance, and sustainable development. It is pivotal to state that literature on BSC in the current setting is limited $[16,18]$, especially concerning the power sector. Therefore, the current study is enriched with literature to support the phenomenon in the contextual setting of developing countries, exclusively in the context of Pakistan. Likewise, the literature on BSC is disjointed and based on confusion for understanding and implications [91]; therefore, the current investigation traces the true essence of the phenomenon. Moreover, the current research framework is unique, which has not been studied widely, especially in the power sector. In this way, the current study is a prime source for power generation organizations to adopt and implement the framework to gain a sustainable competitive advantage that is unique in approach.

Practical implications: The implications of the research are multifaceted for managers, HR professionals, and top strata of manufacturing firms, generally, and for energy organizations specifically. Firstly, the study suggests that top management should use the balanced score as a strategic management system as it influences sustainable development since energy organizations are struggling to deal with sustainable development as an emerging issue. Therefore, the balanced scorecard is a suitable tool to resolve the issue as it addresses the financial and non-financial concerns of the organization. Moreover, it is favorable because it supports the social aspects of the business activities that ensure environmental sustainability. Secondly, it also indicates the strength of the relationship between the balanced scorecard and environmental sustainability, which emphasizes that organizations should strive to develop and implement these practices in parallel. Thirdly, the financial perspective has no influence on sustainable development, which reflects that more efforts should be incurred by the customer, internal growth, and learning perspectives compared with the financial perspective to contribute to society positively.

\section{Conclusions}

The study examines the relationship between the strategic management system and sustainable development by using perceived organizational performance as an intervening variable. It is evident from the empirical findings of the study that there is partial mediation of organizational performance 
between strategic management systems and sustainable development. The findings suggest that non-financial measures have better consequences for employees' performance because these measures make them more responsible regarding environmental sustainability. The results are aligned with the findings of Kaplan and Norton [105], who suggested non-financial measures. Hence, it is recommended to emphasize the use of non-financial measures in combination with financials to improve internal business processes in order to ensure environmental sustainability. For example, it is suggested that measures be taken relating to wastage and usage of unique resources rather than traditional measures that can persuade sustainable development. The empirical findings also stress learning and growth that should be taken as a part of routine matters compared with somewhat seasonal activity.

\section{Research Limitation and Future Research}

The study is confined to a few research limitations, similar to other research. The limitations are one of the ways to conduct future research ventures. The first limitation is the selection of sample size. The study used a case-based sample, which makes it difficult to generalize the results. Furthermore, the energy sector is capital intensive; therefore, to study it in-depth requires control variables such as political and regulatory variables to understand it properly. Future researchers may address this challenge using more variables such as political and regulatory issues and socio-cultural aspects, etc. Another limitation is related to the methodological aspect. Although the study design had generalizability and objective reality, there is room to explore the phenomena subjectively. As the BSC system is not mature in the current setting, it would be highly beneficial to explore the problem through a qualitative approach as well. Additionally, the study incorporates the operationalization of environmental sustainability, while two other components, economic and social aspects, cannot be operationalized due to the limitation of time and the scope of the study. Therefore, future studies can use bundles of these factors. Although researchers used modern data analysis techniques through SEM-PLS, which works best for cross-sectional data type, it would also be beneficial to use a longitudinal type of study design. Additionally, future studies can also compare the effect of BSC on different operational levels such as top, middle, and operating levels to measure the level of effect on each stage.

Author Contributions: M.R. contributed to conceptualization, data collection, methodology, and analysis; X.Z. and J.Y. played a role in funding and supervision. S.N. contributed to data analysis by assisting in software handling. S.M. contributed to assembling resources. All authors have read and agreed to the published version of the manuscript.

Funding: This research received no external funding.

Conflicts of Interest: The authors have no conflict of interest.

Ethical Statement: The study complies with the code of conduct of APA, American Psychological Association, and is in accordance with the submissions of Ethical Principles of Psychologists. Before sending the questionnaire, the consent of participants was ensured through telephonic conversation with their supervisors and HR department, and anonymity of respondents was realized completely. The respondents were identified with the help of their supervisors. All the research was carried out under the supervision of the Chinese professor at North China Electric Power University, as the author is affiliated with the same institute but is originally from Pakistan.

\section{References}

1. Singh, R.K.; Arora, S.S. The adoption of balanced scorecard: An exploration of its antecedents and consequences. Benchmarking Int. J. 2018, 25, 874-892. [CrossRef]

2. Punniyamoorthy, M.; Murali, R. Balanced score for the balanced scorecard: A benchmarking tool. Benchmarking Int. J. 2008, 15, 420-443. [CrossRef]

3. Kaplan, R.S.; Norton, D.P. The Balanced Scorecard: Measures That Drive Performance. Harv. Bus. Rev. 1992, 70, 71-79.

4. Kaplan, R.S.; Norton, D.P. Transforming the Balanced Scorecard from Performance Measurement to Strategic Management: Part I. Account. Horiz. 2001, 15, 1.

5. Ardito, L.; Dangelico, R.M. Firm environmental performance under scrutiny: The role of strategic and organizational orientations. Corp. Soc. Responsib. Environ. Manag. 2018, 25, 426-440. [CrossRef] 
6. Walls, J.L.; Berrone, P.; Phan, P.H. Corporate governance and environmental performance: Is there really a link? Strateg. Manag. J. 2012, 33, 885-913. [CrossRef]

7. Alani, F.S.; Khan, M.F.R.; Manuel, D.F. University performance evaluation and strategic mapping using balanced scorecard (BSC) case study-Sohar University, Oman. Int. J. Educ. Manag. 2018, 32, 689-700. [CrossRef]

8. Bontis, N.; Bart, C.K.; Bose, S.; Thomas, K. Applying the balanced scorecard for better performance of intellectual capital. J. Intellect. Cap. 2007, 8, 652-665.

9. Wang, M. Issues of Balanced Scorecard and Its Implication for Chinese Companies; Auckland University of Technology: Auckland, New Zealand, 2016.

10. Williams, S. Drive your business forward with the Balanced Scorecard. Manag. Serv. 2001, 45, 28-30.

11. Soderberg, M.; Kalagnanam, S.; Sheehan, N.T.; Vaidyanathan, G. When is a balanced scorecard a balanced scorecard? Int. J. Product. Perform. Manag. 2011, 60, 688-708. [CrossRef]

12. Davis, S.; Albright, T. An investigation of the effect of balanced scorecard implementation on financial performance. Manag. Account. Res. 2004, 15, 135-153. [CrossRef]

13. Baumgartner, R.J.; Rauter, R. Strategic perspectives of corporate sustainability management to develop a sustainable organization. J. Clean. Prod. 2017, 140, 81-92. [CrossRef]

14. Kaplan, R.S.; Norton, D.P. Having trouble with your strategy? Then map it. Harv. Bus. Rev. 2000, 78, 167-176. [PubMed]

15. Tariq, M.; Ahmed, A.; Ahmed, S.; Rafi, S.K. Investigating the Impact of Balanced Scorecard on Performance of Business: A study based on the Banking Sector of Pakistan. IBT J. Bus. Stud. (JBS) 2013, 9, 1.

16. Rabbani, F.; Lalji, S.N.; Abbas, F.; Jafri, S.W.; Razzak, J.A.; Nabi, N.; Jahan, F.; Ajmal, A.; Petzold, M.; Brommels, M. Understanding the context of balanced scorecard implementation: A hospital-based case study in Pakistan. Implement. Sci. 2011, 6, 31. [CrossRef]

17. Al-Najjar, S.M.; Kalaf, K.H. Designing a balanced scorecard to measure a bank's performance: A case study. Int. J. Bus. Adm. 2012, 3, 44. [CrossRef]

18. Ahmad, S.T.; Hasnu, S.A.F. Balanced Scorecard Implementation: Case Study of COMSATS Abbottabad. Researcher 2013, 5, 88-109.

19. CPEC. Energy companies in Pakistan. Available online: https://obortunity.org/cpec-news/energy-projects/ (accessed on 15 October 2019).

20. Pearce, J.A.; Robbins, K. Toward improved theory and research on business turnaround. J. Manag. 1993, 19, 613-636. [CrossRef]

21. Pearce II, J.A.; Robbins, D.K. Strategic transformation as the essential last step in the process of business turnaround. Bus. Horiz. 2008, 51, 121-130. [CrossRef]

22. Boulton, W.R. Business Policy: The Art of Strategic Management; Macmillan: New York, NY, USA, 1984.

23. Krasniqi, B.A.; Tullumi, M. What Perceived Success Factors Are Important for Smalll Business Owners in A Transition Economy? Int. J. Bus. Manag. Stud. 2013, 5, 21-32.

24. Ronda-Pupo, G.A.; Díaz-Contreras, C.; Ronda-Velázquez, G.; Ronda-Pupo, J.C. The role of academic collaboration in the impact of Latin-American research on management. Scientometrics 2015, 102, 1435-1454. [CrossRef]

25. Ronda-Pupo, G.A. Growth and consolidation of strategic management research: Insights for the future development of strategic management. Acad. Strateg. Manag. J. 2015, 14, 155.

26. Wright, M.; Stigliani, I. Entrepreneurship and growth. Int. Small Bus. J. 2013, 31, 3-22. [CrossRef]

27. Mintzberg, H. The structuring of Organizations; Pearson: London, UK, 1979.

28. Furrer, O.; Thomas, H.; Goussevskaia, A. The structure and evolution of the strategic management field: A content analysis of 26 years of strategic management research. Int. J. Manag. Rev. 2008, 10, 1-23. [CrossRef]

29. Guerras-Martin, L.Á.; Madhok, A.; Montoro-Sánchez, Á. The evolution of strategic management research: Recent trends and current directions. BRQ Bus. Res. Q. 2014, 17, 69-76. [CrossRef]

30. Grant, R.M. Contemporary Strategy Analysis: Text and Cases Edition; John Wiley \& Sons: Hoboken, NJ, USA, 2016.

31. Molina-Azorín, J.F. Microfoundations of strategic management: Toward micro-macro research in the resource-based theory. BRQ Bus. Res. Q. 2014, 17, 102-114. [CrossRef]

32. Kenworthy, T.P.; Verbeke, A. The future of strategic management research: Assessing the quality of theory borrowing. Eur. Manag. J. 2015, 33, 179-190. [CrossRef] 
33. Ronda-Pupo, G.; Guerras-Martín, L. Dynamics of the scientific community network within the strategic management field through the Strategic Management Journal 1980-2009: The role of cooperation. Scientometrics 2010, 85, 821-848. [CrossRef]

34. Hoskisson, R.E.; Shi, W.; Yi, X.; Jin, J. The evolution and strategic positioning of private equity firms. Acad. Manag. Perspect. 2013, 27, 22-38. [CrossRef]

35. Pettigrew, A.; Thomas, H.; Whittington, R. Strategic management: The strengths and limitations of a field. Handb. Strategy Manag. 2002, 544. [CrossRef]

36. Banker, R.D.; Hu, N.; Pavlou, P.A.; Luftman, J. CIO reporting structure, strategic positioning, and firm performance. MIS Q. 2011, 35, 487-504. [CrossRef]

37. Jensen, J.A.; Cobbs, J.B.; Turner, B.A. Evaluating sponsorship through the lens of the resource-based view: The potential for sustained competitive advantage. Bus. Horiz. 2016, 59, 163-173. [CrossRef]

38. Lin, Y.; Wu, L.-Y. Exploring the role of dynamic capabilities in firm performance under the resource-based view framework. J. Bus. Res. 2014, 67, 407-413. [CrossRef]

39. Babafemi, I.D. Corporate strategy, planning and performance evaluation: A survey of literature. J. Manag. Policies Pract. 2015, 3, 43-49. [CrossRef]

40. Mavondo, F.T.; Tsarenko, Y. Organisational learning profiles: Implications for innovation and performance. In Marketing, Technology and Customer Commitment in the New Economy; Springer: Berlin/Heidelberg, Germany, 2015; pp. 98-103.

41. Beyene, K.T.; Shi, C.S.; Wei, W.W. Linking national culture and product innovation performance: What really influences the interplay, strategy formulation or implementation effectiveness? Int. J. Bus. Manag. 2016, 11, 184. [CrossRef]

42. Bisbe, J.; Malagueño, R. Using strategic performance measurement systems for strategy formulation: Does it work in dynamic environments? Manag. Account. Res. 2012, 23, 296-311. [CrossRef]

43. Maia, J.L.; Serio, L.; Alves Filho, A.G. Almost two decades after: A bibliometric effort to map research on strategy as practice using two data sources. Eur. J. Econ. Financ. Adm. Sci. 2015, 73, 7-31.

44. Smith, M.; Bititci, U.S. Interplay between performance measurement and management, employee engagement and performance. Int. J. Oper. Prod. Manag. 2017, 37, 1207-1228. [CrossRef]

45. Jarzabkowski, P.; Kaplan, S.; Seidl, D.; Whittington, R. On the Risk of Studying Practices in Isolation: Linking What, Who and How in Strategy Research. Strateg. Organ. Forthcom. 2015. [CrossRef]

46. Jarzabkowski, P.; Kaplan, S.; Seidl, D.; Whittington, R. On the risk of studying practices in isolation: Linking what, who, and how in strategy research. Strateg. Organ. 2016, 14, 248-259. [CrossRef]

47. Bromiley, P.; Rau, D. Missing the point of the practice-based view. Strateg. Organ. 2016, 14, $260-269$. [CrossRef]

48. Bromiley, P.; Rau, D. Towards a practice-based view of strategy. Strateg. Manag. J. 2014, 35, 1249-1256. [CrossRef]

49. Okumus, F.; Köseoglu, M.A.; Morvillo, A.; Altin, M. Scientific progress on strategic management in hospitality and tourism: A state-of-the-art. Tour. Rev. 2017, 72, 261-273. [CrossRef]

50. Kaplan, R.S.; Davenport, T.H.; Robert, N.P.D.K.S.; Kaplan, R.S.; Norton, D.P. The Strategy-Focused Organization: How Balanced Scorecard Companies Thrive in the New Business Environment; Harvard Business Press: Brighton, Ma, USA, 2001.

51. Lucianetti, L. The impact of the strategy maps on balanced scorecard performance. Int. J. Bus. Perform. Manag. 2010, 12, 21-36. [CrossRef]

52. Figge, F.; Hahn, T.; Schaltegger, S.; Wagner, M. The sustainability balanced scorecard-linking sustainability management to business strategy. Bus. Strategy Environ. 2002, 11, 269-284. [CrossRef]

53. Nathan, M.L. 'Lighting tomorrow with today': Towards a (strategic) sustainability revolution. Int. J. Sustain. Strateg. Manag. 2010, 2, 29-40. [CrossRef]

54. Farid, D.; Mirfakhredini, H. Balanced scorecard application in universities and higher education institutes: Implementation guide in an Iranian context. Univ. Bucur. An. Ser. Stiinte Econ. Si Adm. 2008, 2, 29.

55. Saunders, M.; Mann, R.; Smith, R. Implementing Strategic initiatives: A framework of leading practices. Int. J. Oper. Prod. Manag. 2008, 28, 1095-1123. [CrossRef]

56. Free, C.; Qu, S.Q. The use of graphics in promoting management ideas: An analysis of the Balanced Scorecard, 1992-2010. J. Account. Organ. Chang. 2011, 7, 158-189. [CrossRef] 
57. Stede, W.A.V.d.; Chow, C.W.; Lin, T.W. Strategy, choice of performance measures, and performance. Behav. Res. Account. 2006, 18, 185-205. [CrossRef]

58. Tung, A.; Baird, K.; Schoch, H.P. Factors influencing the effectiveness of performance measurement systems. Int. J. Oper. Prod. Manag. 2011, 31, 1287-1310. [CrossRef]

59. Ferreira, A.; Otley, D. The design and use of performance management systems: An extended framework for analysis. Manag. Account. Res. 2009, 20, 263-282. [CrossRef]

60. Ittner, C.D.; Larcker, D.F.; Rajan, M.V. The choice of performance measures in annual bonus contracts. Account. Rev. 1997, 231-255.

61. Ittner, C.D.; Larcker, D.F. Innovations in performance measurement: Trends and research implications. J. Manag. Account. Res. 1998, 10, 205.

62. Banker, R.D.; Potter, G.; Srinivasan, D. An empirical investigation of an incentive plan that includes nonfinancial performance measures. Account. Rev. 2000, 75, 65-92. [CrossRef]

63. Hoque, Z.; James, W. Linking balanced scorecard measures to size and market factors: Impact on organizational performance. J. Manag. Account. Res. 2000, 12, 1-17. [CrossRef]

64. Hoque, Z. 20 years of studies on the balanced scorecard: Trends, accomplishments, gaps and opportunities for future research. Br. Account. Rev. 2014, 46, 33-59. [CrossRef]

65. Baird, K.; Su, S. The association between controls, performance measures and performance. Int. J. Product. Perform. Manag. 2018, 67, 967-984. [CrossRef]

66. De Geuser, F.; Mooraj, S.; Oyon, D. Does the balanced scorecard add value? Empirical evidence on its effect on performance. Eur. Account. Rev. 2009, 18, 93-122. [CrossRef]

67. Radomska, J. The concept of sustainable strategy implementation. Sustainability 2015, 7, 15847-15856. [CrossRef]

68. Cierna, H.; Sujova, E. Parallels between corporate social responsibility and the EFQM excellence model. MM Sci. J. 2015, 10, 670-676. [CrossRef]

69. Chalmeta, R.; Palomero, S. Methodological proposal for business sustainability management by means of the Balanced Scorecard. J. Oper. Res. Soc. 2011, 62, 1344-1356. [CrossRef]

70. Hristov, I.; Chirico, A.; Appolloni, A. Sustainability Value Creation, Survival, and Growth of the Company: A Critical Perspective in the Sustainability Balanced Scorecard (SBSC). Sustainability 2019, 11, 2119. [CrossRef]

71. Stead, J.G.; Stead, W.E. The coevolution of sustainable strategic management in the global marketplace. Organ. Environ. 2013, 26, 162-183. [CrossRef]

72. Rafiq1a, M.; Zhang, X.; Yuan, J.; Naz, S. A Meta-synthesis Study on the Political and Regulatory RisNs of Chinese Power Companies Investing in PaNistan. Int. J. Comput. Eng. 2018, 3, 151.

73. Hansen, E.G.; Schaltegger, S. The sustainability balanced scorecard: A systematic review of architectures. J. Bus. Ethics 2016, 133, 193-221. [CrossRef]

74. Duman, G.M.; Taskaynatan, M.; Kongar, E.; Rosentrater, K.A. Integrating environmental and social sustainability into performance evaluation: A Balanced Scorecard-based Grey-DANP approach for the food industry. Front. Nutr. 2018, 5, 65. [CrossRef]

75. Dias-Sardinha, I.; Reijnders, L.; Antunes, P. From environmental performance evaluation to eco-efficiency and sustainability balanced scorecards. Environ. Qual. Manag. 2002, 12, 51-64. [CrossRef]

76. Falle, S.; Rauter, R.; Engert, S.; Baumgartner, R. Sustainability management with the sustainability balanced scorecard in SMEs: Findings from an Austrian case study. Sustainability 2016, 8, 545. [CrossRef]

77. Kramer, S. Strategic Sustainability: The Case of the New Zealand Energy Sector. Master Thesis, Victoria University of Wellington, Wellington, New Zealand, 2009.

78. Henrique da Rocha Vencato, C.; Maffini Gomes, C.; Luciane Scherer, F.; Marques Kneipp, J.; Schoproni Bichueti, R. Strategic sustainability management and export performance. Manag. Environ. Qual. Int. J. 2014, 25, 431-445. [CrossRef]

79. Yilmaz, A.K.; Flouris, T. Managing corporate sustainability: Risk management process based perspective. Afr. J. Bus. Manag. 2010, 4, 162-171.

80. Epstein, M.J.; Wisner, P. Good neighbours: Implementing social and environmental strategies with the BSC. Balanced Scorec. Rep. 2001, 3, 8-11.

81. Araújo, M.; Sampaio, P. The path to excellence of the Portuguese organisations recognised by the EFQM model. Total Qual. Manag. Bus. Excell. 2014, 25, 427-438. [CrossRef] 
82. Veress, Z.E.; Gavreliuc, A. Organizational Commitment, Organizational Justice and Work Satisfaction: A Comprehensive Model in a Romanian Organizational Setting. Rom. J. Psychol. 2018, 20. [CrossRef]

83. Porter, M.E.; Reinhardt, F.L. A strategic approach to climate. Harv. Bus. Rev. 2007, 85, 22.

84. Adams, R.; Jeanrenaud, S.; Bessant, J.; Denyer, D.; Overy, P. Sustainability-oriented innovation: A systematic review. Int. J. Manag. Rev. 2016, 18, 180-205. [CrossRef]

85. Bhattacharya, C.; Polman, P. Sustainability lessons from the front lines. MIT Sloan Manag. Rev. 2017, 58, 71.

86. Hart, S.L. Beyond greening: Strategies for a sustainable world. Harv. Bus. Rev. 1997, 75, 66-77.

87. Stadtler, L.; Lin, H. Moving to the next strategy stage: Examining firms' awareness, motivation and capability drivers in environmental alliances. Bus. Strategy Environ. 2017, 26, 709-730. [CrossRef]

88. Engert, S.; Rauter, R.; Baumgartner, R.J. Exploring the integration of corporate sustainability into strategic management: A literature review. J. Clean. Prod. 2016, 112, 2833-2850. [CrossRef]

89. Pope, J.; Annandale, D.; Morrison-Saunders, A. Conceptualising sustainability assessment. Environ. Impact Assess. Rev. 2004, 24, 595-616. [CrossRef]

90. González-Benito, Ó.; González-Benito, J. Implications of market orientation on the environmental transformation of industrial firms. Ecol. Econ. 2008, 64, 752-762. [CrossRef]

91. Testa, F.; Rizzi, F.; Daddi, T.; Gusmerotti, N.M.; Frey, M.; Iraldo, F. EMAS and ISO 14001: The differences in effectively improving environmental performance. J. Clean. Prod. 2014, 68, 165-173. [CrossRef]

92. Siva, V.; Gremyr, I.; Bergquist, B.; Garvare, R.; Zobel, T.; Isaksson, R. The support of Quality Management to sustainable development: A literature review. J. Clean. Prod. 2016, 138, 148-157. [CrossRef]

93. Braam, G.J.; Nijssen, E.J. Performance effects of using the balanced scorecard: A note on the Dutch experience. Long Range Plan. 2004, 37, 335-349. [CrossRef]

94. Malina, M.A.; Selto, F.H. Communicating and controlling strategy: An empirical study of the effectiveness of the balanced scorecard. J. Manag. Account. Res. 2001, 13, 47-90. [CrossRef]

95. Becker, B.; Gerhart, B. The impact of human resource management on organizational performance: Progress and prospects. Acad. Manag. J. 1996, 39, 779-801.

96. Bell, E.; Bryman, A.; Harley, B. Business Research Methods; Oxford university press: Oxford, UK, 2018.

97. Bell, E.; Bryman, A. The ethics of management research: An exploratory content analysis. Br. J. Manag. 2007, 18, 63-77. [CrossRef]

98. M'maiti, H.I. Balanced Score Card as A Strategic Management Tool in the Kenyan Commercial State Corporations. Master's Thesis, University Of Nairobi, Nairobi, Kenya, 2014.

99. Pallant, J. SPSS survival guide. Crow's Nest; Allen \& Unwin: Crows Nest, Australia, 2005.

100. Yang, B. Factor analysis methods. In Research in organizations: Foundations and methods of inquiry.; Berrett-Koehler: San Francisco, CA, USA, 2005; pp. 181-199.

101. Tavakol, M.; Dennick, R. Making sense of Cronbach's alpha. Int. J. Med Educ. 2011, 2, 53. [CrossRef]

102. Alarcón, D.; Sánchez, J.A.; De Olavide, U. Assessing convergent and discriminant validity in the ADHD-R IV rating scale: User-written commands for Average Variance Extracted (AVE), Composite Reliability (CR), and Heterotrait-Monotrait ratio of correlations (HTMT). In Proceedings of the Spanish STATA Meeting, Madrid, Spain, 22 October 2015; pp. 1-39.

103. Henseler, J.; Ringle, C.M.; Sarstedt, M. A new criterion for assessing discriminant validity in variance-based structural equation modeling. J. Acad. Mark. Sci. 2015, 43, 115-135. [CrossRef]

104. Dodge, Y. The Oxford Dictionary of Statistical Terms; International Statistical Institute: Voorburg, The Netherlands, 2003.

105. Kaplan, R.S.; Norton, D.P. The strategy map: Guide to aligning intangible assets. Strategy Leadersh. 2004, 32, 10-17. [CrossRef]

(C) 2020 by the authors. Licensee MDPI, Basel, Switzerland. This article is an open access article distributed under the terms and conditions of the Creative Commons Attribution (CC BY) license (http://creativecommons.org/licenses/by/4.0/). 